\title{
Creating a Libyan Earthquake Archive: From Classical Times to the Present
}

\author{
Somaia S. Suwihli1 ${ }^{12 *}$, Thomas R. Paradise ${ }^{1}$ \\ ${ }^{1}$ Department of Geosciences, University of Arkansas, Fayetteville, USA \\ ${ }^{2}$ Department of Geography, University of Benghazi, Benghazi, Libya \\ Email: *ssuwihli@uark.edu
}

How to cite this paper: Suwihli, S.S. and Paradise, T.R. (2020) Creating a Libyan Earthquake Archive: From Classical Times to the Present. Open Journal of Earthquake Research, 9, 367-382.

https://doi.org/10.4236/ojer.2020.94021

Received: July 1, 2020

Accepted: August 17, 2020

Published: August 20, 2020

Copyright $\odot 2020$ by author(s) and Scientific Research Publishing Inc. This work is licensed under the Creative Commons Attribution International License (CC BY 4.0).

http://creativecommons.org/licenses/by/4.0/

\begin{abstract}
Libya's seismicity has been considered relatively minor, however, several earthquakes of magnitude larger than 5.0 have occurred since Roman times. The scope of this study is to identify and chronicle past seismic frequency and magnitude in Libya by translating, analyzing, and compiling historical sources and archaeological data of Libya's seismic history. The earliest references to earthquakes have been found in historic records and archaeological data since $262 \mathrm{AD}$. Archaeological evidence was found to support Latin records that stated that the shock destroyed much Cyrene also affecting most of the Province of Cyrenaica. In $704 \mathrm{AD}$, a large shock destroyed towns and villages across the Sebha region. While in 1183, a violent tremor shook Tripoli. In 1935 and 1939, a series of large earthquakes struck the Hun Graben area, including one of magnitude 7.1 on April 19, 1935-considered the strongest earthquake in Libyan history. The coast of northeastern Libya in Al-Jabal Al-Akhdar areas continues to be a seismically active region. In 1963, the Roman outpost of Barca (modern Al-Marj) was razed by an earthquake of moderate magnitude $(5.6 \mathrm{Ml})$. Offshore earthquakes with magnitudes of 5.6 and 4.9 occurred in Tripoli in 1974 and 1976. In addition, several tremors of 4 to 5.6 magnitude were recorded in northeastern and northwestern Libya between 1990 and 2019. With little previous knowledge of Libya's quake history, an estimate of seismic periodicity and event consequences is problematic. Such an archive of seismic hazards (frequency, location, magnitude) is fundamental to estimating seismic risk (future events, consequences).
\end{abstract}

\section{Keywords}

Libya Earthquake, Seismic Activity, Frequency, Magnitude, Richter, North Africa

\section{Introduction}

The seismic activities in Libya have been considered relatively minor [1], how- 
ever, several earthquakes of magnitude larger than 5.0 have been documented in different areas in the country [2] [3] [4]. Though its history is relatively less seismically active and damaging than some other sites, nevertheless, a series of relatively recent earthquakes with magnitudes (Richter) up to 7 occurred on April 19, 1935; it has been described as the strongest earthquake in Libya's history, and one of the largest earthquakes in Africa's history [5] [6]. The ancient and recent history, of earthquakes in a region located on the Mediterranean boundary of the African Shield, is particularly interesting. The complicated geologic structures between Eurasia and Africa, the corresponding plate movement, and the underlying driving forces, lead to strong variations in seismic hazard throughout the area. Libya, located on the Mediterranean foreland at the northcentral margin of the African continent, has experienced considerable tectonic activities, especially along its northern coast [7]. An understanding of the regional seismicity related to this seismo-tectonic setting mostly depends on the data from instrumental records, so many historical earthquakes of the past are rarely known or recorded. Identifying prehistoric and historic earthquake hazards and history is an important component of predicting the causes and effects of future earthquakes and the assessment of risk (i.e. deaths, injury, and economic loss) because past earthquakes suggest the location, magnitude, and size of future earthquakes [8].

To better understand earthquake hazards, regional tectonics, and the presentday evolution of Libya's seismicity, this study addresses the region's earthquakes from Roman records, to the monitoring of modern national geophysical centers and global seismic data, to create a comprehensive earthquake archive. This earthquake archive can be used to 1) create Libya's first national earthquake policies for effective mitigation (i.e. planning, policy, engineering, education), 2) a foundation to create structural construction standards, and to 3) assist in the preparation for future hazardous events and risk assessment. These findings are expected to contribute to the greater understanding of the earthquake activity in Libya, and to advance knowledge of regional earthquakes in Libya, across North Africa, and the Mediterranean Basin.

\section{Geologic Setting of Libya}

Libya is located in the Northeast African Tectonic Zone which is bordered by the Gulf of Aqaba and Red Sea to the East. The northeastern portion of the African Continent represents the contact between the African, Arabian, and Eurasian/Anatolian Plates (Figure 1). These plates are involved in the geodynamic reconstructions of the south part of the east of Mediterranean [9]. The models of plate tectonic suggest the African plate is moving northward relative to the Eurasian plate at a rate of $\sim 6 \mathrm{~mm} /$ year [10] [11] while the Arabian plate is moving north-northwest toward Eurasia at a rate of about $\sim 18 \mathrm{~mm} /$ year [12]. Due to these movements, crustal spreading is occurring along the axis of the Red Sea and left-lateral slip along the Dead Sea Transform Zone. The different rates of 
movement between Africa and Arabia ( $12 \mathrm{~mm}$ /year) is taken-up by a left-lateral motion along the Dead Sea Transform Fault [6] [13] [14]. Corti et al. [15] suggested that the Red Sea Rift is transferring compressional stress to Libya and western Egypt, generating significant earthquakes along the southeastern Mediterranean where earthquakes are widely felt and have caused widespread damage [12] [16].

\section{Methodology}

This archive developed a baseline of past and current seismic inventory in Libya, and that is by providing the dates, locations, and magnitudes of seismic events

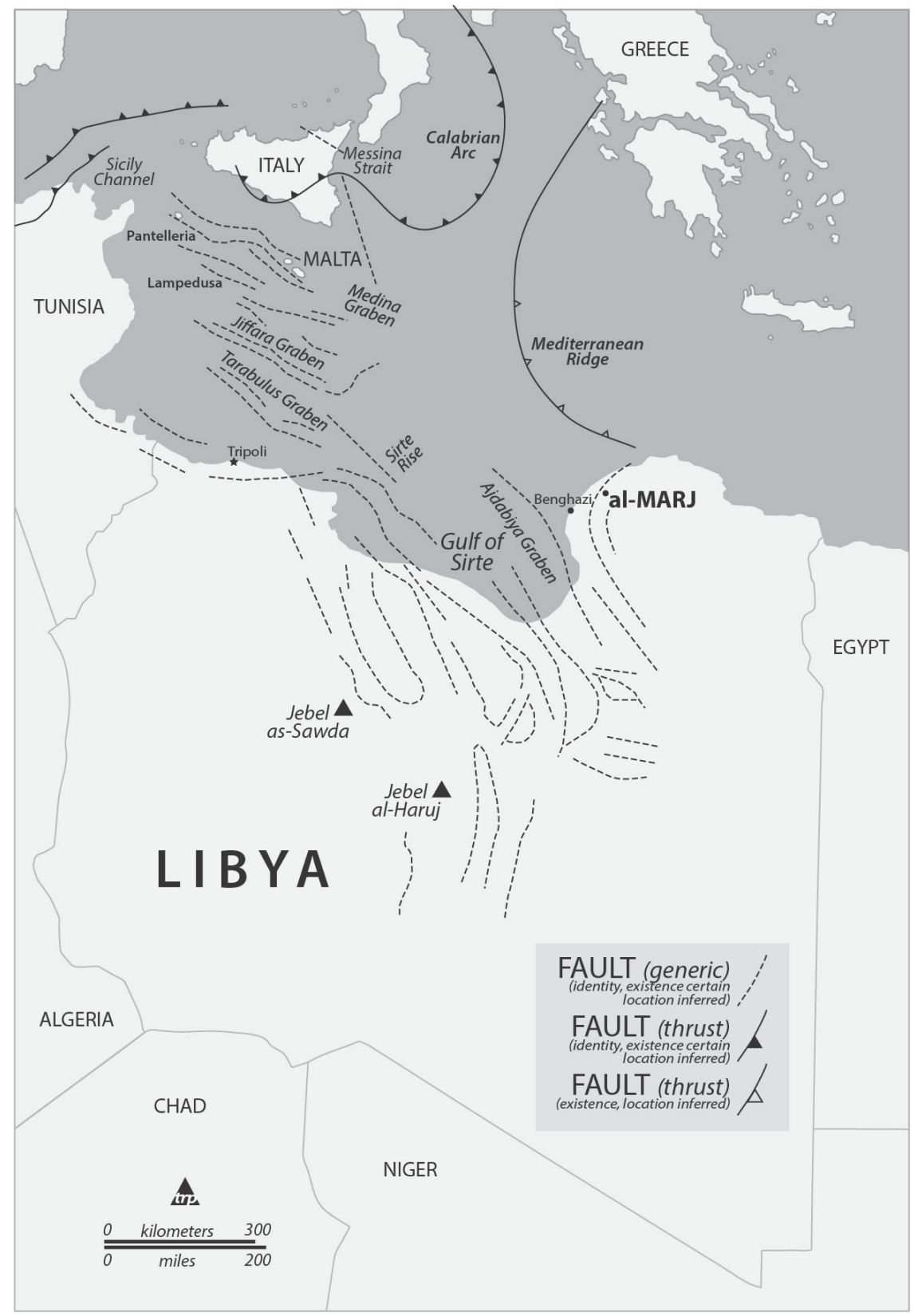

Figure 1. Tectonic map of Central Mediterranean Sea and Tripolitania-Sirte Basin, Libya [17]. Cartography by authors, 2020. 
(when possible). In order to incorporate both quantitative and qualitative methods, this study used multimedia records, documents, and past archives of Libya's earthquake history (i.e. written records, newspapers, film, images). By translating Latin codices, records and texts, and Arabic, French, Italian, and English records, oral histories, newsreels, and news sources, the authors created an archive representing the earliest earthquake activity in Libya from the Classical period (262 AD) to our modern times from varied multi-lingual sources.

The collection of historical and ancient seismic events relied upon a combination of historical records, and archaeological data when recorded information was not extant. Seismic records were rare in ancient times, so the archive relies upon archaeological data. Guidoboni [18] with the collaboration of Comastri and Traina, as well as Ambraseys et al. [16] published catalogues of earthquakes in which Libya events were included. Dating of early earthquakes was derived from the archaeological chronological evidence provided by dated artifacts of known/estimated age (i.e. ceramics, coins) excavated above and below the ruinsa conventional technique [19].

For example, in the cities of Sabratha (NW Libya) and Cyrene (NE Libya), the dates of their razing by earthquakes was dated by 1) Greek Christian inscriptions [18] [20] and 2) excavated coins unearthed in the quake-related rubble and ruins [21] [22] [23]. Excavation and dating of artifacts related to structural collapse and debris is widely used and has proven itself valuable and quite accurate when records are subsequently discovered that corroborate the dates of the temblors, and the estimated intensity and magnitudes of the events.

In the early $20^{\text {th }}$ century, Sieberg [24] discussed Libyan historical earthquakes in his comprehensive tome of earthquakes of the region, Erdbebengeographi. Such descriptive catalogues, known for their in-depth classical compilations, are often the only primary works and translations used to identify these early quakes (i.e. Tripolitania 1183). However, in this research, it was the lacunae of these early catalogues that required updating from antiquity to into the $20^{\text {th }}$ Century [4] [24].

Dates, information, and narratives from $20^{\text {th }}$ Century earthquakes were collected and revised from varied sources including compilations from Rudolph [25] in addition to French findings from Critikos [26], Italian research from Cavasino [27] and Lipparini [28], data from U.S National Geophysical Center and Solar-Terrestrial Data Center in Kebeasy's study [29], Ambraseys' work [2] [16], and United States Geological Survey (USGS)-ANSS Comprehensive Earthquake Catalog (ComCat) Documentation [30].

These assorted archives provided information about real-time earthquakes through online archives, seismic maps, statistics, and related descriptions. Using this broad method with in-depth translations, and assorted mixed sources assisted in the compilation of these archaeologic, historic, and modern seismic data to create a baseline inventory of past-present seismic activity. Then, the data were presented in form of maps and graphs by using ArcMap program and pro- 
vide the collected seismic data of this study. The data include the date, latitude and longitude, magnitude, and depth $(\mathrm{km})$ of seismic events upon which the Libyans may add, improve, and supplement this archive. In addition, through this new chronology, cartographic representations can be produced in the hopes of creating a baseline GIS database from which further earthquakes may be added.

\section{Results}

\subsection{Antiquity-1900}

In this study, seismic events (dates and locations) have been separated into two groups from 262 A.D. to 1900 (Table 1, Figure 2), and from 1900 to the present (Table 2, Figure 3) when new technologies emerged that increased accurate event records. The earliest earthquake in Libya has been documented in 262 A.D [22] [31] and was recorded in the Historia Augusta during the consulship of Gallienus and Faustinus. At the time, there were a number of serious earthquakes across the Mediterranean, specifically in Rome, Libya, and Asia Minor [18].

In 262 A.D, this early earthquake caused considerable damage across Libya. The shock affected all of the province of Cyrenaica, however, the devastation was focused on the city of Cyrene (or observed and recorded in better detail) where archaeological evidence of the destruction was provided by Roman ruins. The city was razed to such a degree that it was rebuilt in 267 under the new name Claudiopolis for "meliorem fortunam" or better luck/fortune [22] (Figure 2).

Table 1. Historic earthquakes affecting Libya, up to 1900.

\begin{tabular}{|c|c|c|c|c|c|c|}
\hline \multicolumn{3}{|c|}{$\begin{array}{l}\text { Date A. D. } \\
\text { Year m: d: }\end{array}$} & Level of Effects & $\begin{array}{c}\text { Location } \\
\text { Lat }{ }^{\circ} \mathrm{N} \text { Long }{ }^{\circ} \mathrm{E}\end{array}$ & $\begin{array}{l}\text { Magnitude } \\
\text { (Descriptive) }\end{array}$ & Location and Remarks \\
\hline \multicolumn{3}{|c|}{262} & Damage & E. Mediterranean & Large & Cyrene and other cities destroyed in Cyrenaica region \\
\hline \multicolumn{3}{|c|}{306 to 310} & Damage & N. Libya & Large & Sabratha \\
\hline \multicolumn{3}{|c|}{365} & Damage & N. Libya & & Sabratha \\
\hline \multirow[t]{4}{*}{365} & 7 & 21 & Damage & E. Mediterranean & & Cyrenaica \\
\hline & 704 & & & S.W. Libya & Large & Towns and villages in Fezzan and Sebha destroyed \\
\hline & 1183 & & Damage & N.W Libya & Large & Tripoli destroyed, 20,000 deaths \\
\hline & 1656 & & Damage & N.W Libya & Large & Tripoli half houses destroyed \\
\hline \multirow{2}{*}{1685} & 5 & 25 & Damage & N.W Libya & Large & Tripoli, $>200$ buildings collapsed \\
\hline & 1803 & & Felt & N.W Libya & Small & Tripoli \\
\hline \multicolumn{3}{|c|}{1811} & Felt & Libya-Egypt border & Large & Siwa Temple Ammon damaged \\
\hline $\begin{array}{c}1853 \\
1853\end{array}$ & $\begin{array}{r}8 \\
10\end{array}$ & $\begin{array}{l}5 \\
11\end{array}$ & Felt & S.W Libya & Small & Murzuq \\
\hline 1870 & 6 & 24 & Felt & N. Libya & Small & Benghazi \\
\hline 1881 & 6 & 10 & Felt & Libya-Tunisia border & Small & Eastern Tunisia, between Gabes and Meret \\
\hline 18 & & 8 & Damage & W. Libya & Small & Ghadamis \\
\hline
\end{tabular}

Sources: Sieberg [24], Goodchild [22], Bono [35], Ambraseys [2], Ambraseys [16], Guidoboni [18], di Vita-Evrard [33]. 


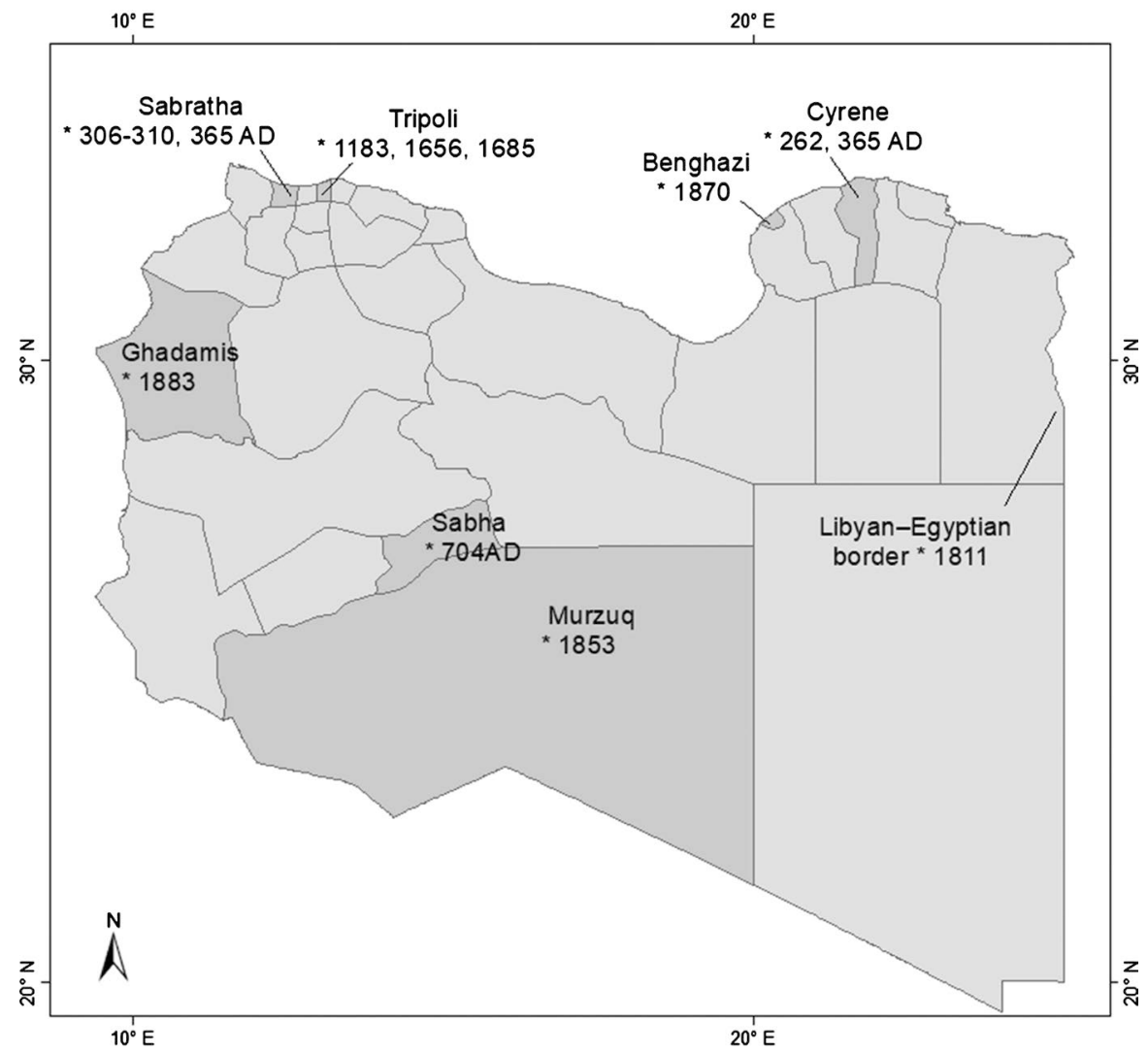

Figure 2. The map shows the seismic regions of Libya with event dates from Antiquity to 1900 [2] [16] [18] [22] [24] [33] [35]. Cartography by authors, 2020.

Evidence from the architectural rubble from Cyrene indicated that the angle of column drum fall can indicate the direction of epicenter/focus, while sediment components above and below the remnants can be used to identify the date of the tremor [22]; architectural ruins are now a conventional means of identifying the time, location, and relative magnitude of severe earthquakes [19].

During the Fourth Century, between 306 and $310 \mathrm{AD}$ and again in $365 \mathrm{AD}$ the city of Sabratha - located on the Mediterranean coast about 70 kilometers (40 Miles) west of Tripoli — was hit by two destructive earthquakes [32]. The first earthquake razed many private houses and inflicted a heavy toll on the public buildings of the city. After having been destroyed, the buildings were rebuilt and restored in 340 - $350 \mathrm{AD}$. The $365 \mathrm{AD}$ earthquake shook Sabratha to an even greater degree. This time it was razed to the ground and none of its temples were rebuilt because the new faith, Christianity, forbade it. Also, the forum lost its full colonnade, yet the pavement of the north portico was obviously rebuilt [33] (Figure 2).

Cyrenaica was hit again by an earthquake in 365AD. According to reliable archaeological evidence and documentation, and recalled in literary and epigraphic sources, this earthquake destroyed the public buildings across the city [22] [34]. Further excavation has unearthed several collapsed structures containing buried skeletons, which confirmed the severe magnitudes of these historic quakes. 


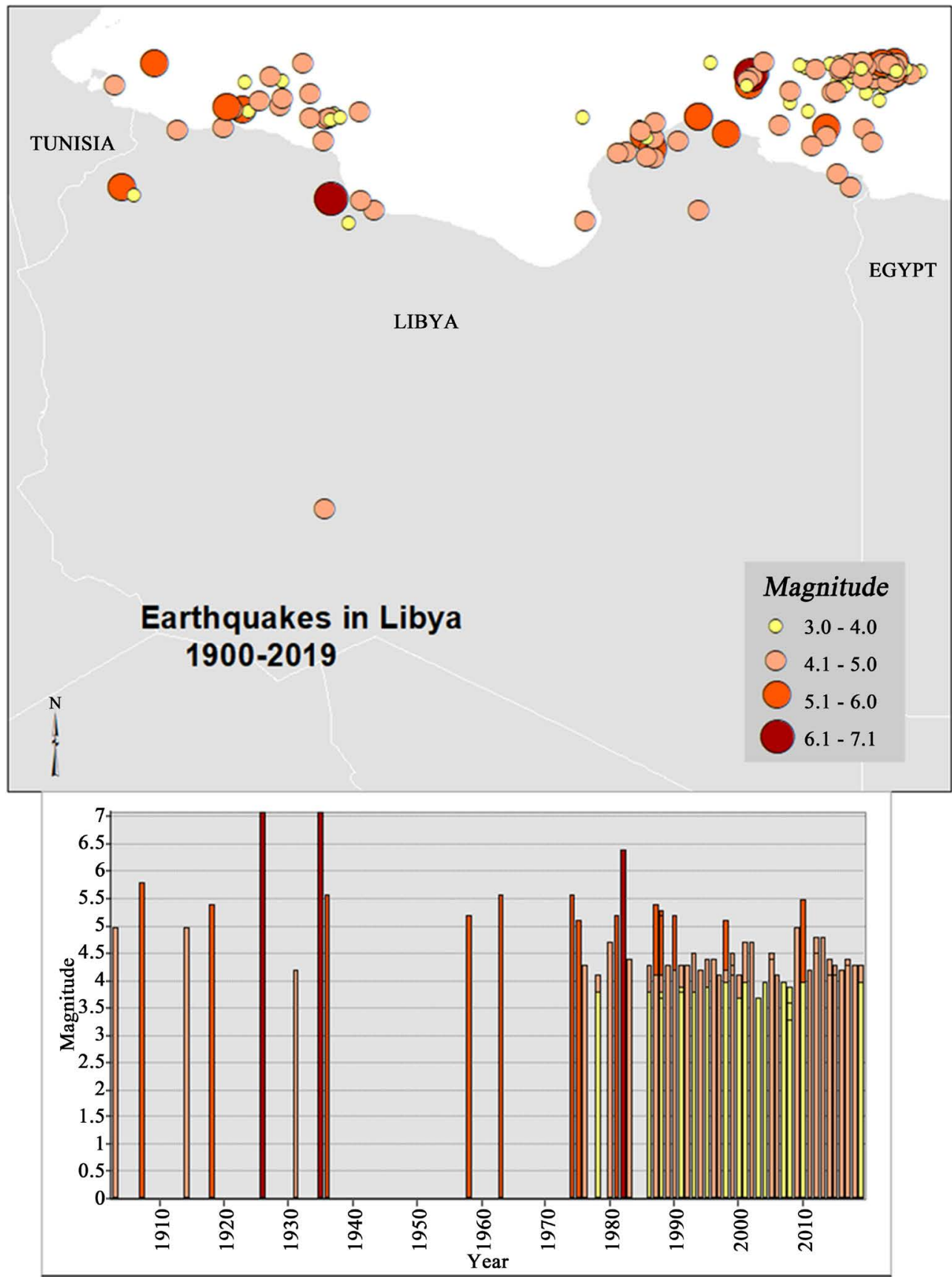

Figure 3. Earthquakes affecting Libya between 1900 and $2019(M \geq 3.0)$. This map and graph represent the distribution of the earthquakes that have occurred in or near Libya $\left(20^{\circ} \mathrm{N}-34^{\circ} \mathrm{N}\right.$, $\left.10^{\circ} \mathrm{E}-25^{\circ} \mathrm{E}\right)$ with color-coded events identified chronologically and spatially. Note the recent swarms (low magnitude 3 - 4) between 1990 and 2019 that are more frequent than previous events [3] [4] [30] [38]. Graphic by authors, 2020.

Such damage, dated by inscriptions and coins, occurred after 364 and before 378AD [23]. A painted Greek Christian inscription was found in the necropolis on Demetria's Tomb in Cyrene that records in visual detail, the death of Demetria and her son in an earthquake in the late of 4th Century [18]. During this period of increased seismicity, similar destruction, however lesser, was recorded 
along the northwest coast of Libya dated by numismatic evidence [23].

Sieberg [24] reported that four major earthquakes occurred before the 1930s in Libya. A large shock struck in 704AD that destroyed many towns and villages in the Sabha Territory and the adjacent Fezzan Province. Then in 1183 a great earthquake shook Tripoli nearly destroying the city and killing roughly 20,000 people. With the exception of the earthquakes in $704 \mathrm{AD}$ and 1183 the first severe earthquake in Tripolitania, reported in early texts, occurred toward the end of 1656. It was strong and destroyed nearly half of the structure in Tripoli. The shaking and related seiche causing the sinking of five pirate vessels in the port [2]. On May 25, 1685 a tremor hit Tripoli and caused the collapse of more than 200 buildings. This event was reported in the flysheet contained in an anonymous letter sent to a merchant in Ancona from Tripoli [35].

In 1803, an earthquake of moderate magnitude was recorded to have occurred in Tripoli [16]. Then in 1811, a tremor occurred near the Egyptian border, in the Libyan desert near Siwa, razing the Temple of Ammon at the Siwa Oasis [29]. Many shocks were felt on 5 August, 1853 in Murzuq in the Fezzan Region, and again on 11 October in the same year. On December 22, 1860, on the edge of the Little Desert on the Libyan border with Tunisia, a violent shock was centered in Matmata, $320 \mathrm{~km}$ (200 miles) west of Tripoli. It knocked people to the ground, however, no structures were damaged or destroyed.

In August 1883, Ghadamis - which lies about $462 \mathrm{~km}(287 \mathrm{mi})$ to the southwest of Tripoli, near the border with Tunisia and Algeria - was shaken by a temblor which caused great damages, injury, and death. The severe shaking was accompanied by loud explosive booms, which were reportedly heard within 350 $\mathrm{km}$ of the town, implying a very large magnitude quake [16] (Figure 2).

\subsubsection{0-Present Earthquakes}

After 1900, the number of reported earthquakes increased because of better instrumentation and advancements in innovating more sensitive seismographs, seismometers, and timing systems, so that earthquakes could be better located through triangulation [36]. Accompanying this progress was a new interest in earthquake research and the advancement of the nascent field of seismology [2] [3] [22] [24] [29] [37] [38]. Gordon and Engdahl [39] in their instrumental study of the Libyan 1963 Earthquake, they used the standard C\&GS hypocenter program to compute the locations of the main earthquake and the two largest aftershocks to gain an appreciation of possible differences between seismic records of earthquakes contrasted with records of large explosions. Hassen [7] investigated the seismic activity and its relationship to the geology and tectonics of Libya. Articles and commentaries now appeared in the local press, and in different regional and national publications across Libya. However, such notices were brief and gave few details, with little information that could be used to determine the locations (i.e. epicenters) of the events. However, what could be gleamed from these various sources from 1900-2019 have been compiled and listed (Figure 3, Figure 4). 
Libya's Seismic Periodicity (since 1900)

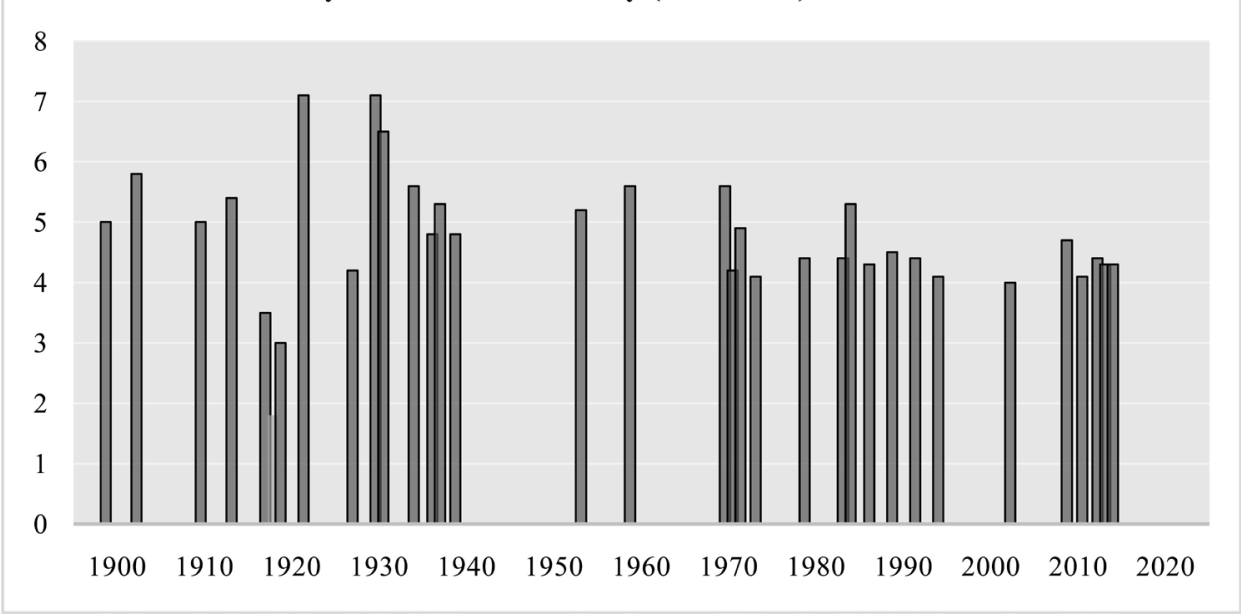

Figure 4. Earthquakes affecting Libya from 1903-2017 with magnitudes ranging from 4 - 8 (MR) [30] [38]. Graphic by authors, 2020.

An earthquake struck Tripoli on 22 November, 1903 [25] but caused little damage. The shocks were stronger inland, focused in the Tarhuna Region. The earthquake was not recorded by the early Italian Seismic Network, yet some of the European stations described the event [2]. The Earthquake of 18 May, 1914 was strongly felt and demolished the fort at Gheddahia, and caused some damage to two other nearby forts. This shock was widely recorded by European seismological stations, but an attempt at an instrumental location of the quake did not succeed [28].

In 1926, a large earthquake was felt at Cyrenaica and Tripoli striking the eastern part of the Mediterranean Ridge on 26 June [26]. On 30 August, 1926 an earthquake felt by nearly everyone was felt across Benghazi and Derna. The intensity indicates a higher magnitude than was reported on the 26 June 1926 event [27].

Between 1935 and 1939, a series of large earthquakes shook the Hun Graben area, west of the Gulf of Sirte. One of the first quakes to hit during this period occurred on 19 April, 1935 with a magnitude 7.1 (MI). Striking the desert region along the west coast of the Gulf of Sirte between Zlitan, Bani Walid, Bu Nujaym, and Sirte, although not of a severe magnitude, it one of the most violent quakes in Africa's modern history. However, since the epicenter was in the desert the population was sparse and no damage was reported. This earthquake was followed by two large aftershocks of magnitudes 6.0 and 6.5. Several smaller aftershocks followed this shock [29].

On January 23, 1939, an earthquake with a magnitude between 5.6 and 5.9 occurred in the same area. This shock took place in Gheddahia, $100 \mathrm{~km}(62$ miles) southern Misratah, and was followed by four tremors [29]. These earthquakes continued for three days shaking the coastal cities of Tripoli, al-Khums, Misratah, Buwayrat, and Sirte [16]. A major earthquake then followed six years later $80 \mathrm{~km}$ (50 miles) to the southeast of the 1935 mainshock on 4 March, 1941 
with a 5.6 magnitude [29].

This seismically active region east of the Hun Graben, extends NNW along the western side of the Gulf of Sirte. Several shocks have been recorded with epicenters on the eastern side of this gulf. The observed seismic activity of the eastern Hun Graben and its extension into the Mediterranean Sea forms the western side of the Gulf of Sirte, and the activity along the east of the gulf boundary suggests that the gulf area is subjected to continual and significant tectonic movement creating raised flanks (Libya mainland) with a depressed central plate (Gulf) [29].

The northeastern coast of Libya in the region of Al-Jabal Al-Akhdar continues to be seismically active. The modern town of Al-Marj-the Roman outpost city of Barce - had a population of 13,000 in 1963 when it was razed by an earthquake of 5.6 magnitude at 17:14 (local time) on 21 February. The earthquake is renowned in Libya, not because of its magnitude, but because of the loss of life [37] [39]. Many structures collapsed killing 300 and injuring 375 people. Moreover, the whole population was left homeless [3] [38]. It was followed by five small aftershocks [39]. The poorly constructed stone, fired clay, and adobe-brick structures found in the city were responsible for injuries, deaths, and property damage. Structures constructed of rubble stone with mud or clay mortar suffered extensive damage [37].

Tripoli continued to be seismically active where in 1974 and 1976 offshore earthquakes with magnitudes of 5.6 and 4.9 occurring across the region [2] [6] [40]. In addition, a number of tremors of 4 to 4.7 magnitude (MI) were recorded across northern coastal Libya from 1990 into 2019 [30] (Table 2).

\section{Discussion}

Since the seismic history of Libya extends back at least 1700 years, the periodicity and location of earthquakes is crucial to better understanding the factors that influence its quakes, and those that affect the determination of seismic risk across Libya today. The identification of accurate earthquake locations and epicenters before 1930 is difficult because of the absence of records, whether written, film, or oral. This difficulty should be seen simply as poor reporting in sources lacking regional descriptions rather than in any lack of seismic activity. Also, it is possible that due to scarce seismic records, we are unaware of one or more large historic earthquakes across the region. The recorded number of earthquakes in Libya before the 1980s does not represent the actual number due to the small number of seismological stations in the region, and the limitations of instrument sensitivity. This fact was confirmed in a reconnaissance survey carried out in the Gharyan area in February 1977. A more sensitive and accurate vertical seismograph was used for only six hours, and it recorded three moderate earthquakes; these earthquakes were not reported by any other seismological stations [29].

The Eastern Mediterranean region was affected by major tectonic activity 
Table 2. Earthquakes affecting Libya and Libyan Offshore 1900-2019 ( $M \geq 4.0)$.

\begin{tabular}{|c|c|c|c|c|c|c|c|}
\hline \multicolumn{3}{|c|}{$\begin{array}{l}\text { Date A. D. } \\
\text { Year m: d: }\end{array}$} & \multirow{2}{*}{$\begin{array}{c}\text { Time G. M. T. } \\
\text { H: m: s: } \\
\text {--- }\end{array}$} & \multicolumn{2}{|c|}{$\begin{array}{c}\text { Location } \\
\text { Lat }^{\circ} \mathrm{N} \text { Long }{ }^{\circ} \mathrm{E}\end{array}$} & \multirow{2}{*}{$\begin{array}{c}\begin{array}{c}\text { Magnitude } \\
\text { (Descriptive or Richter) }\end{array} \\
5.0\end{array}$} & \multirow{2}{*}{$\begin{array}{c}\text { Location and Remarks } \\
\text { Tripoli }\end{array}$} \\
\hline 1903 & 11 & 22 & & 32.80 & 13.20 & & \\
\hline 1907 & 2 & 2 & 09:04:00 & 33.0 & 21.00 & 5.8 & Offshore in North Cyrenaica \\
\hline 1914 & 5 & 18 & 10:46:00 & 31.30 & 22.00 & 5.0 & Violent earthquake demolished Gheddahia blockhouse \\
\hline 1918 & 10 & 14 & 14:06:00 & 33.0 & 22.0 & 5.4 & Offshore: $10 \mathrm{~km} \mathrm{~N}$ of Susa \\
\hline 1919 & 8 & 3 & ---- & 31.5 & 19.5 & ---- & Offshore: East Gulf of Sirte \\
\hline 1926 & 6 & 26 & ---- & \multicolumn{2}{|c|}{ Hellenic arc } & Small & Cyrenaica and Tripoli \\
\hline 1926 & 8 & 30 & 12:40:00 & \multicolumn{2}{|c|}{ Hellenic arc } & 7.1 & Benghazi and Derna \\
\hline 1931 & 4 & 24 & $15: 21: 00$ & 32.1 & 19.9 & 4.2 & Offshore: East Gulf of Sirte \\
\hline 1935 & 4 & 19 & $15: 23: 22$ & 31.5 & 15.2 & 7.1 & In area of Hun Graben \\
\hline 1935 & 4 & 20 & 05:10:51 & 31.0 & 15.5 & 6.5 & 8 tremors recorded in this area in the period April 19-29, 1935 \\
\hline 1936 & 6 & 13 & 00:32:39 & 32.7 & 22.5 & $5.3-5.9$ & $15 \mathrm{~km}$ West of Derna \\
\hline 1939 & 1 & 23 & $02: 22: 46$ & 31.5 & 16.0 & 5.6 & Gheddahia, aftershocks in cities along Libyan Coast \\
\hline 1940 & 1 & 2 & ---- & 30.3 & 22.0 & 4.8 & South of Jabal al Akhdar area \\
\hline 1941 & 3 & 4 & 23:45:00 & 30.7 & 15.7 & $5.3-5.9$ & Hun Graben area \\
\hline 1941 & 5 & 3 & $23: 45: 10$ & 33.3 & 23.5 & ---- & Offshore: $100 \mathrm{~km} \mathrm{NE}$ of Derna \\
\hline 1943 & 7 & 16 & 01:54:00 & 33.0 & 21.5 & 4.8 & Offshore: $\sim 45 \mathrm{~km}$ WNW of Susa \\
\hline 1948 & 5 & 22 & ---- & 33.3 & 23.5 & ---- & Offshore: $100 \mathrm{~km} \mathrm{NE}$ of Derna \\
\hline 1957 & 5 & 2 & 02:00:00 & \multicolumn{2}{|c|}{----} & Minor & Felt in Northern Cyrenaica \\
\hline 1958 & 5 & 17 & $05: 25: 33$ & 31.8 & 11.3 & 5.2 & Jabal Nefusa area, E. Nalut \\
\hline 1963 & 2 & 21 & $17: 14: 31$ & 32.6 & 20.9 & 5.6 & Barce (Al-Marj) badly damaged \\
\hline 1974 & 9 & 4 & $06: 29: 16$ & 33.05 & 13.5 & 5.6 & Tripoli \\
\hline 1975 & 01 & 01 & 07:03:51 & 32.4 & 21.2 & 4.2 & Al-Marj \\
\hline 1976 & 12 & 19 & $21: 21: 53$ & 33.01 & 13.97 & 4.9 & Tripoli \\
\hline 1978 & 6 & 7 & $07: 21: 21$ & 25.7 & 15.0 & 4.1 & North of Murzuq \\
\hline 1983 & 10 & 17 & 22:39:07 & 31.2 & 15.9 & 4.4 & North of Sirte \\
\hline 1988 & 01 & 28 & 19:12:17 & 32.2 & 21.1 & 4.4 & Al-Marj \\
\hline 1988 & 01 & 28 & 05:48:08 & 32.4 & 21.1 & 5.3 & Al-Marj \\
\hline 1990 & 05 & 18 & $18: 27: 51$ & 31.7 & 24.7 & 4.3 & North of Batnan \\
\hline 1993 & 09 & 9 & $00: 32: 40$ & 32.3 & 20.6 & 4.5 & Al-Marj \\
\hline 1996 & 10 & 30 & 10:43:02 & 32.3 & 20.5 & 4.4 & North of Benghazi \\
\hline 1999 & 11 & 7 & $14: 43: 35$ & 32.6 & 21.1 & 4.1 & Al-Marj \\
\hline 2007 & 9 & 3 & $11: 58: 38$ & 31.5 & 11.5 & 4.0 & North of Nalut \\
\hline 2013 & 5 & 11 & $04: 42: 37$ & 32.7 & 12.3 & 4.7 & North of Zuwarah \\
\hline 2015 & 10 & 3 & $22: 47: 55$ & 32.2 & 21.0 & 4.1 & Al-Marj \\
\hline 2017 & 5 & 2 & 09:43:12 & 31.9 & 24.5 & 4.4 & WNW of Bardiyah \\
\hline 2017 & 11 & 11 & 19:00:48 & 32.75 & 20.92 & 4.3 & NNE of Al-Marj \\
\hline 2019 & 2 & 21 & 02:19:32 & 32.57 & 21.62 & 4.3 & Bayda \\
\hline
\end{tabular}

Sources: Cavasino [27], Critikos [26], Campbell [38], Ambraseys [3], Suleiman [4], USGS [30]. 
between the middle of the Fourth Century to the middle of the Sixth Century, often termed: the Early Byzantine Tectonic Paroxysm (EBTP). Modern geological studies indicate a clustering of high magnitude earthquakes around the Eastern Mediterranean shores during this time [32].

The 365 A.D event is most likely to be identified with a Hellenic Arc Subduction Zone event of large $(M>8)$ magnitude [23]. Historical and archaeological data support the hypothesis that the Fourth to Sixth Centuries exhibited increased quake periodicity across the Eastern Mediterranean Basin. Although there are no specific statistics for these historic events, widespread damage, injury, and death occurred in 262, 365, 704, 1183, 1656, and 1685 suggesting large magnitudes for these events $(>7)$. Therefore, the data on historical earthquakes are of crucial importance to our understanding of Libya's relatively unknown seismic history.

If a historic record exists of one or more large earthquakes in a region, it is a likely location for similar earthquakes at some time in the future [41] [42] [43]. Throughout our historic epochs, the western edge of the Sirte basin, including the Hun Graben, has been one of the most seismically active regions in Libya. The 1935 Hun Graben Earthquake shook with a 7.1 magnitude and struck north-central Libya. It was largely caused by regional tectonics and the geological history of the North African craton-the segment most likely to cause severe tremors in the future.

Quake locations from 1900-2019 strongly suggest that most of the seismic activities are clustered in three areas: 1) the north-northwest trending Hun Graben which extends in the Mediterranean in the north, and in the middle of Libya in the south, 2) the Al Jabal Al Akhdar in northeast Libya and extends in the Mediterranean in the north, 3) the east-western axis from the Tunisian borders to $\mathrm{Al}$ Aziziya to Houn. In the area surrounding Hun Graben, most of the seismic events are concentrated along the eastern coast of the NW-SE trending Hun Graben, and 4) the rest of the Libyan territories not included in the above three regions. This region is not seismologically active (Figure 5). More recent activity (1939-1972) seems to have extended northeast from the Graben into the Mediterranean Sea (Figure 3). If the active fault zone associated with the 1935 and 1941 Earthquakes extends toward the northwest, it may represent a significant risk to the cities of Al-Khums (201,943), Zlitan (109,972), and Misratah $(386,120)$ with 700,000 lives affected [44]. These three modern cities represent more than $10 \%$ of Libya's population in 2018. Seismic activity seems to be concentrated near Al-Marj, at the western edge of al-Jabal Al-Akhdar as well. After the 1963 earthquake series, tremors then followed in 1975, 1988, 1993, 1999, and 2015. This suggests that the area is still tectonically active. The locations of epicenters in this area corroborate the current understanding as a zone associated with the collisional boundary between Africa and Eurasia. The eastern side of the Sirte Basin Rift System is less active nowadays, with relatively no activity within the basin itself (Figure 3). 


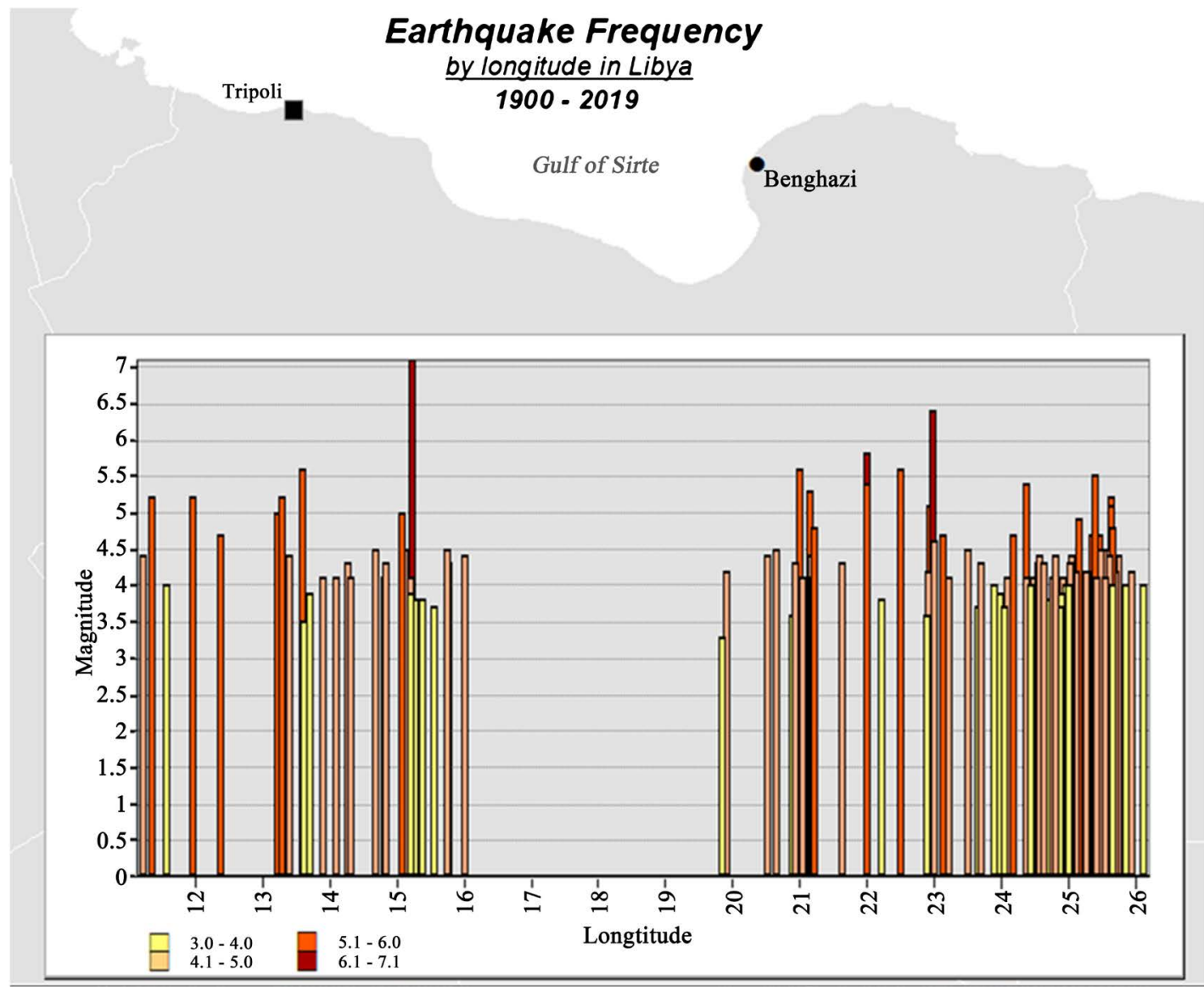

Figure 5. Libya's recent earthquake epicenters-when spatially represented-show distinct seismic regions: West (III) and East (II). Libya's central region along the Gulf of Sirte, displays a dramatically decreased frequency in recorded earthquakes since 1900 [3] [4] [30] [38]. Graphic by authors, 2019.

\section{Conclusion}

From the overview provided in this research, it is evident that our knowledge of earthquakes in Libya between the $3^{\text {rd }}$ century AD and 1935 is based on a meager number of archaeologic and historic records. These specific findings contribute to discussions of the need for further research that seeks to understand the earthquake activity in Libya. The historic and geographic factors that could account for missing seismic periods have to identified and examined when preparing a feasibility study aiming at collecting new data on past seismic events in Libya. To understand future seismic risk of earthquakes in Libya, it is imperative that we understand Libya's seismic history and hazards all in the hopes of decreasing seismic risk and its grim consequences of injury, death, loss, and damage [45].

\section{Acknowledgements}

The authors are grateful to the Interlibrary Loan Department at the University of Arkansas Libraries, which supports the research needs by providing access to materials not owned by the University Libraries. 


\section{Conflicts of Interest}

The authors declare no conflicts of interest regarding the publication of this paper.

\section{References}

[1] Gutenberg, B. and Richter, C.F. (1965) Seismicity of the Earth and Associated Phenomena. Hafner Pub., New York.

[2] Ambraseys, N.N. (1984) Material for the Investigation of the Seismicity of Tripolitania (Libya). In: Brambati, A. and Slejko, D., Eds., The O.G.S. Silver Anniversary Volume, O. G. S., Trieste, 143-153.

[3] Ambraseys, N.N. (1994) Material for the Investigation of the Seismicity of Libya. Libyan Studies, 25, 7-22. https://doi.org/10.1017/S0263718900006191

[4] Suleiman, A.S., Albini, P. and Migliavacca, P. (2004) A Short Introduction to Historical Earthquakes in Libya. Annals of Geophysics, 47, 545-554.

[5] Johnston, A.C. (1989) The Seismicity of "Stable Continental Interiors". In: Earthquakes at North-Atlantic Passive Margins. Neotectonics and Postglacial Rebound, Kluwer, Dordrecht, 299-327. https://doi.org/10.1007/978-94-009-2311-9 18

[6] Suleiman, A.S. and Doser, D.I. (1995) The Seismicity, Seismotectonics and Earthquake Hazards of Libya, with Detailed Analysis of the 1935 April 19, M = 7.1 Earthquake Sequence. Geophysical Journal International, 120, 312-322.

https://doi.org/10.1111/j.1365-246X.1995.tb01820.x

[7] Hassen, H.A. (1983) Seismicity of Libya and Related Problem.

[8] Burton, I., Kates, R. and White, G. (1993) The Environment as Hazard. Second Edition, Guilford Press, New York.

[9] Abou Elenean, K.M. (2007) Focal Mechanisms of Small and Moderate Size Earthquakes Recorded by the Egyptian National Seismic Network (ENSN), Egypt. NRIAG Journal of Astronomy and Geophysics, 6, 119-153.

[10] Salamon, A., Hofstetter, A., Garfunkel, Z. and Ron, H. (2003) Seismotectonics of the Sinai Subplate-The Eastern Mediterranean Region. Geophysical Journal International, 155, 149-173. https://doi.org/10.1046/j.1365-246X.2003.02017.x

[11] Reilinger, R., et al. (2006) GPS Constraints on Continental Deformation in the Africa-Arabia-Eurasia Continental Collision Zone and Implications for the Dynamics of Plate Interactions. Journal of Geophysical Research: Solid Earth, 111, 1-26. https://doi.org/10.1029/2005JB004051

[12] Mourabit, T., et al. (2014) Neo-Deterministic Seismic Hazard Assessment in North Africa. Journal of Seismology, 18, 301-318. https://doi.org/10.1007/s10950-013-9375-2

[13] McClusky, S., Reilinger, R., Mahmoud, S., Ben Sari, D. and Tealeb, A. (2003) GPS Constraints on Africa (Nubia) and Arabia Plate Motions. Geophysical Journal International, 155, 126-138. https://doi.org/10.1046/j.1365-246X.2003.02023.x

[14] El-Fiky, G.S. (2000) Crustal Strains in the Eastern Mediterranean and Middle East as Derived from GPS Observations. Bull. Earthq. Res. Institute, Univ. Tokyo, 75, No. December, 105-125.

[15] Corti, G., Cuffaro, M., Doglioni, C., Innocenti, F. and Manetti, P. (2006) Coexisting Geodynamic Processes in the Sicily Channel. In: Dilek, Y. and Pavlides, S., Eds., Postcollisional Tectonics and Magmatism in the Mediterranean Region and Asia, 409, No. 05, Geological Society of America Special Paper, 83-96. 
https://doi.org/10.1130/2006.2409(05)

[16] Ambraseys, N.N., Melville, C.P. and Adams, R.D. (1995) The Seismicity of Egypt, Arabia and the Red Sea: A Historical Review. Cambridge University Press, Cambridge. https://doi.org/10.1017/CBO9780511524912

[17] Capitanio, F.A., Faccenna, C., Funiciello, R. and Salvini, F. (2011) Recent Tectonics of Tripolitania, Libya: An Intraplate Record of Mediterranean Subduction. Geological Society, London, Special Publications, 357, 319-328. https://doi.org/10.1144/SP357.17

[18] Guidoboni, E., Comastri, A. and Traina, G. (1994) Catalogue of Ancient Earthquakes in the Mediterranean Area up to the 10th Century. ING, Roma-SGA, Bologna.

[19] Joukowsky, M.S. (2002) The Petra Great Temple: A Nabataean Architectural Miracle. Near Eastern Archaeology, 65, 235-248. https://doi.org/10.2307/3210860

[20] Di Vita, A. (1995) Archaeologists and Earthquakes: The Case of 365 A.D. Annali di Geofisica, 38, 971-976.

[21] Goodchild, R.G. (1966) A Coin Hoard from "Balagrae" (El-Beida), and the Earthquake of AD 365. Libya Antiqua, 3-4, 203-212.

[22] Goodchild, R.G. (1968) Graeco-Roman Cyrenaica, Geology and Archaeology of Narthern Cyrenaica, Libya. Geogr. Archaeol. North, Cyyrenaica, 23-40.

[23] Stiros, S.C. (2001) The AD 365 Cret Earthquake and Possible Seismic Clustering during the Fourth to Sixth Centuries AD in the Eastern Mediterranean: A Review of Historical and Archaeological Data. Journal of Structural Geology, 23, 545-562. https://doi.org/10.1016/S0191-8141(00)00118-8

[24] Sieberg, A. (1932) Erdbebengeographie. Handbuch der Geophysik, 4, 708-744.

[25] Rudolph, E. (1905) Katalog der im Jahre 1903 bekannt gewordenen Erdbeben. Wilhelm Engelmann.

[26] Critikos, N.A. (1928) Le tremblement de terre de la mer de Crete du 26 juin 1926. Ann. l'Observatoire Natl. d'Athènes, 10, XXXIX-XLVII, 10.

[27] Cavasino, A. (1927) Macrosismi avvertiti in Italia e Colonie nell'anno 1926. Bollettino della Società Sismologica Italiana, 26, 25-40.

[28] Lipparini, T. (1940) Tettonica e geomorfologia della Tripolitania. Bollettino della Societa Geologica Italiana, 59, 221-301.

[29] Kebeasy, R.M. (1980) Seismicity and Seismotectonics of Libya. Geol. Libya, 3, 954963.

[30] United States Geological Survey (USGS) (2019) ANSS Comprehensive Earthquake Catalog (ComCat) Documentation. U.S. Geological Survey.

[31] Vita-Finzi, C. (2010) Letter from Libya: Epigraphy and Landscape. Antiquity, 84, 558-561. https://doi.org/10.1017/S0003598X00066783

[32] Pirazzoli, P., Laborel, J. and Stiros, S. (1996) Earthquake Clustering in the Eastern Mediterranean during Historical Times. Journal of Geophysical Research: Solid Earth, 101, 6083-6097. https://doi.org/10.1029/95JB00914

[33] di Vita-Evrard, G. (1999) Libya: The Lost Cities of the Roman Empire. Konemann.

[34] White, D. (1967) L'agora di Cirene. I Lati Nord ed Est della Platea Inferiore. American Journal of Archaeology, 71, 414-416. https://doi.org/10.2307/501941

[35] Bono, S. (1982) Storiografia e fonti occidentali sulla Libia, 1510-1911. L’Erma di Bretschneider.

[36] Havskov, J. and Alguacil, G. (2002) Instrumentation in Earthquake Seismology, No. 
358. Springer, Dordrecht.

[37] Minami, J.K. (1965) Relocation and Reconstruction of the Town of Barce, Cyrenaica, Libya, Damaged by Earthquake of 21 February 1963. Third World Conference on Earthquake Engineering, UNESCO, 96-110.

[38] Campbell, A.S. (1968) The Barce (Al Marj) Earthquake of 1963. In: Geology and archaeology of Northern Cyrenaica, Libya, Petroleum Exploration Society, Libya, 183-195.

[39] Gordon, D.W. and Engdahl, E.R. (1963) An Instrumental Study of the Libyan Earthquake of February 21, 1963. Earthquake Notes, 34, 50-56.

https://doi.org/10.1785/gssrl.34.3-4.50

[40] Westaway, R. (1990) The Tripoli, Libya, Earthquake of September 4, 1974: Implications for the Active Tectonics of the Central Mediterranean. Tectonics, 9, 231-248. https://doi.org/10.1029/TC009i002p00231

[41] Kelleher, J., Sykes, L. and Oliver, J. (1973) Possible Criteria for Predicting Earthquake Locations and Their Application to Major Plate Boundaries of the Pacific and the Caribbean. Journal of Geophysical Research, 78, 2547-2585.

https://doi.org/10.1029/JB078i014p02547

[42] Allen, C.R. (1975) Geological Criteria for Evaluating Seismicity. Geological Society of America Bulletin, 86, 1041-1057. https://doi.org/10.1016/B978-0-444-41494-6.50006-0

[43] Shimazaki, K. and Nakata, T. (1980) Time-Predictable Recurrence Model for Large Earthquakes. Geophysical Research Letters, 7, 279-282. https://doi.org/10.1029/GL007i004p00279

[44] “Libya Population 2019” (LP). World Population Review, 2019. https://worldpopulationreview.com/countries/libya-population

[45] Montz, B., Tobin, G. and Hagelman, R. (2017) Natural Hazards: Explanation and Integration. Guilford Publications, New York. 